\title{
ARTHUR F. FISHKIN, PROMINENT BIOCHEMIST AND EDUCATOR
}

Lavinel G. Ionescu

Scienco Scientific Consulting Services

Viamão, RS, BRASIL

and

Sarmisegetusa Research Group

Santa Fe, NM, USA

\begin{abstract}
Arthor Frederic Fishkin was born on May 27, 1930 in New York City, USA and passed away peacefully in his sleep in Ornaha, Nebraska on his $80^{\text {th }}$ birthday, on Moy 27,2010 . He attended elementary and secosdary school in New York, obtained a B.A. in Zoology from Indiana University in 1951 and a M.A. in 1953. He was awarded the Ph. D. Degree in Biochemistry from the University of Lowa in 1957. He held faculty positions at Louisiana State University, New Mexico Srate University and Creighton University. His research activities dealt with enzymes and glycoproteins in connective tissues. He contributed to the training of thousands of students in the medical sciences for almost half a century.
\end{abstract}

KEYWORDS: History of Chemistry and Biochemistry, Glycoproteins in Blood Vessels, Enzymes, Medical Education

\section{RESUMO}

Athur F. Fishlin nasceu em New York, Estados Unidos em 27 de Maio de 1930 e faleceu serenamente no dia de sen $80^{\circ}$ aniversário durante 0 sono em Omaha, Nebraska, Estados Unidos en 27 de Mato de 2010. Ele recebeu os titulos de B.A. E M.A. em Zoologia da Utiversidade de Indiana em 1951 e 1953, respectivanente e o titulo de Ph.D. em Bioqumica da Unersidade de lowa em 1957. Ocupou cargos de professor em Louisiana State University, New Mexico State University e Creighton University. As suas atividades de pesquisa trataram de enzimas e glicoprotelnas em vasos sangutheos. Ele contribuiu na preparaço de milhares de profissionais márea da saude por quase meio século.

PALAVRAS CHAVE: História da Quimica Bioquímica, Glicoproténas em Vasos Sanguíneos, Enzimas, Cducação Médica 
SOUTHERN BRAZILIAN, JOURNAL OF CHEMISTRY SOUTH. BRAZ. J. CHEM. , Vol. 19,No.19, 2011

60

Arthur F. Fishkin, Prominent Riochemist and Educator

Arthur Frederic Fishkin was borm on May 27, 1930 in New York

City, USA and passed away peacefully in his sleep in Omaha, Nebraska, on his $80^{\text {th }}$ birthday, on May $27,2010$.

He was an only child. His parents were Sidney Leonard Fishkin and Ruth Schneiderman Fishkin. His father was a successfull lawyer in New York. His grandfather was originally from Edinet (Yedintzi), in the morthern part of the present day Republic of Moldova and immigrated to the United States of America towards the end of the $19^{\text {th }}$ century (1899).

Arthur F. Fishkin attended Public School 192 and Junior High School 43 in Manhattan. His Bar Mitzvah was held at the Park Avenue Synagogue in New York in 1943. He completed secondary education at the Bronx High School of Sciences and graduated in 1948. He was a member of the Boy Scouts in Manhattan, was elected to the Order of the Arrow and as a youngster enjoyed sports, especially baseball.

He graduated from Indiana University and obtained a Bachelor of Arts Degree in Zoology in 1951. Two years later, in 1953 he was awarded the Master of Arts in Zoology by Indiana University. 
SOUTHERN BRAZILIAN, JOURNAL OF CHEMISTRY SOUTH. BRAZ. J. CHEM., Vol. 19,No.19, 2011

L. G. Ionescu

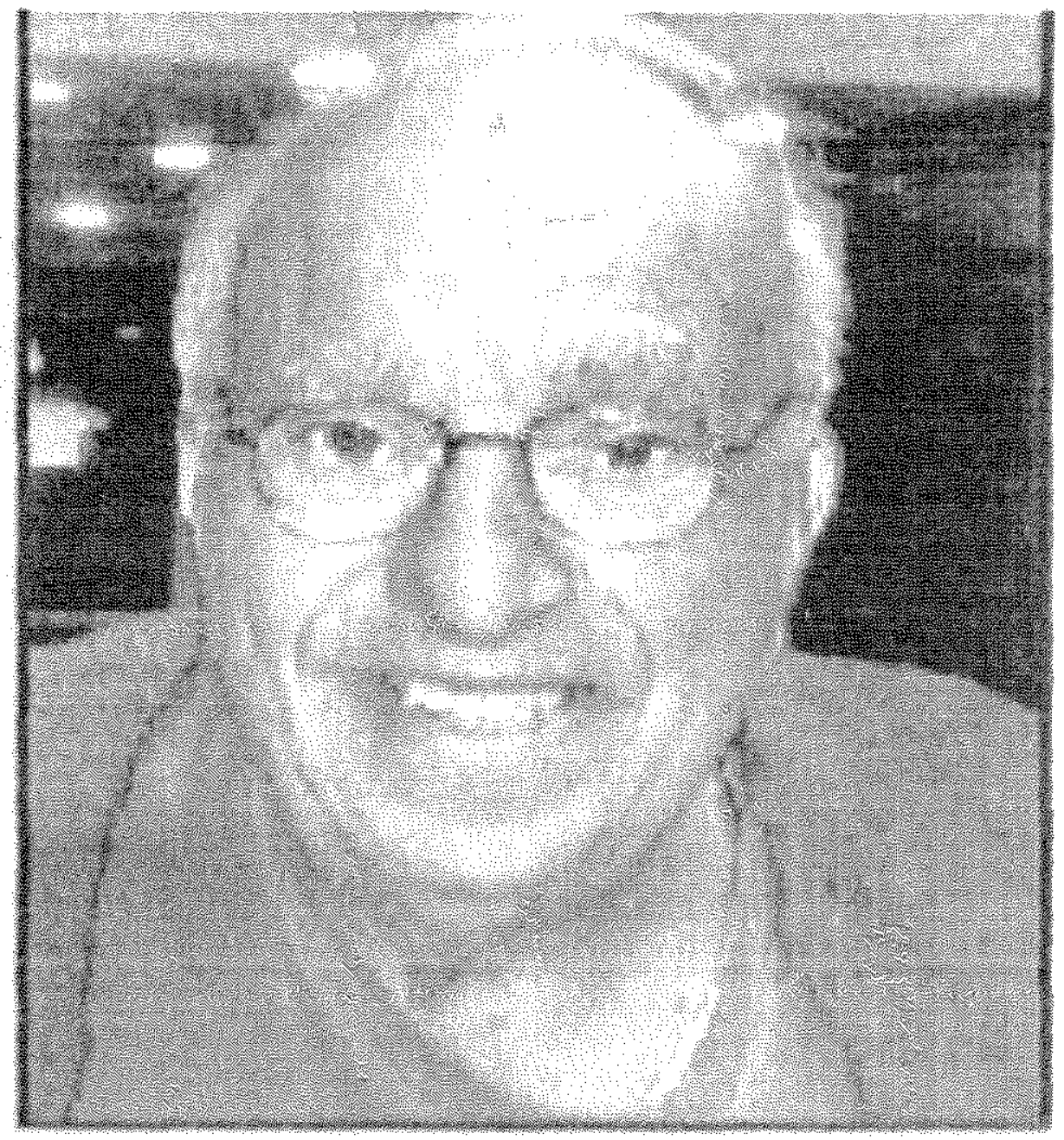

PROF. Dr. ARTHUR F. FISHKIN (1930-2010) 
SOUTH. BRAZ.J. CHEM., Vol.19, No. 19, 2011

Arthur F. Fishkin, Prominent Biochemist and Ealucator

62

Arthur F. Fishkin continued his graduate studies at the University of lowa, where he originally intended to study for a doctorate in zoology. His interest in biochemistry was sparked by his interaction with Prof. Henry Bull and by his course in physical biochemistry. He was awarded the Doctor of Philosophy Degree in Biochemistry in 1957. His research advisor was Professor Gene Lata and his doctoral dissertation involved the investigation of hormones and enzymes. Enzymology was an area in which Prof. Dr. A. F., Fishkin had profound and continuous interest for the rest of his life.

He met Jane Leslie Paul at the University of Iowa and they were married in September 1956 at her home in Bangor, Maine. They were married for 53 years and she survives him. They had four children: Paul A.S. Fishkin, M.D., an oncologist and hematologist of Peoria, Illinois; Charles A. Fishkin, a Senior Vice-President of Alliance Bernstein in New York (married to Suzanne Tinley of Chappaqua, N.Y. ): James A. Fishkin, a partner in legal antitrust practice at Dechert LLP of Washington, D.C.; and Joel A. Fishkin, an economist for the Indiana Utility Regulatory Commission. He was blessed with five grandchildren. 
SOUTH. BRAZ. J. CHEM., Vol.19, No. 19, 2011

\section{G. Iorescu}

Prof. Dr, Arthur F. Fishkin was extremely proud of his children and grandchildren. As a father, he was very encouraging and allowed each one of his sons to find his interests and develop his talents. As a grandfather, he was very gentle and followed with care and interest the development of his grandchildren.

From 1957 to 1958, Dr. A. F. Fishkin was the recipient of a Postdoctoral Fellowship and worked as an Associate Scientist at the Southwest Foundation for Research and Education in San Antonio, Texas.

In 1958 he joined the Louisiana State University School of Medicine in New Orleans as Instructor of Biochemistry and Medicine and collaborated with Professor Gerald S. Berenson doing research on glycoproteins in blood vessels.

In 1962, Dr. Arthur F. Fishkin was promoted to Assistant Professor of Biochemistry and Medicine, a position that he held until 1964.

From 1964 to 1968 he held the academic appointment of Assistant Professor of Chemistry at New Mexico State University in Las Cruces and played an important role in the establishment of the Doctoral Program in Chemistry and Biochemistry. 


\section{SOUTHERN BRAZILIAN, JOURNAL OF CHEMISTRY}

SOUTH. BRAZ. J. CHEM. , Vol. 19,No.19, 2011

In 1968, Prof. Dr. Arthur F. Fishkin moved to Omaha, Nebraska and accepted the position of Associate Professor of Biomedical Sciences in the School of Medicine at Creighton University. He worked in the Biochemistry Department of Creighton University for almost four decades and was promoted to Professor Emeritus of Biomedical Sciences in 2008.

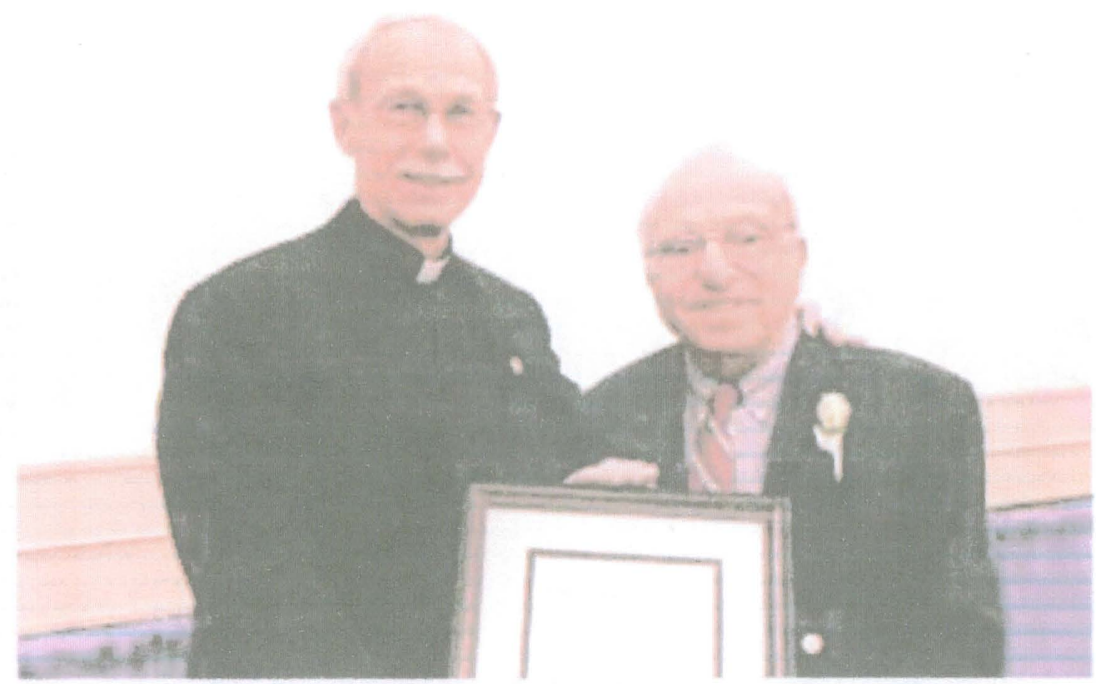

Creighton President the Rev. John P. Schlegel, S.J., presents Fishkin with a plaque, honoring his promotion to professor emeritus, during the 2008 President's Convocation ceremony.

At Creighton University, well known for its "student-centered" approach, Prof. Dr. A.F. Fishkin epitomized this approach. He was always willing to give whatever time was needed to mentor and help students that were having problems in the classroom or in life in general. 
SOUTH. BRAZ. J. CHEM., Vol.19, No. 19, 2011

L. G. Ionescu

He taught biochemistry classes to undergraduate and graduate students in the College of Arts and Sciences, School of Medicine, School of Dentistry, School of Pharmacy and School of Nursing.

During his academic career, Prof. Dr. Arthur F. Fishkin was instrumental in the preparation and education of literally thousands of health professionals over a period that spanned almost half of century, of which about forty years at Creighton University. Sometimes, his students came from two different generations. One interesting case is that of a wedding in Florida, where the bride, Constance Faro, MS'97, MD'02 and the father of the bride, Richard Faro, MD'72 were Prof. Fishkin's medical students.

Prof. Dr. Arthur Fishkin held many administrative positions at Creighton University. Among them we mention, Head of the Division of Biochemistry, Director of Animal Research, Departmental Graduate Coordinator, University Rank and Tenure Committee, Minority Student Committee, Medical School Admissions Committee, Committee on Scholarship and Student Services and others.

A more complete description of Prof. Dr. Arthur F. Fishkin's service to Creighton University is given in the FOUNDERS DAY CONVOCATION of February 12, 2008, reproduced on the following page. 
SOUTHERN BRAZILIAN, JOURNAL OF CHEMISTRY

SOUTH. BRAZ.J. CHEM., Vol. 19,No.19, 2011

Arthur F. Fishkin, Prominent Biochemist and Educator

66

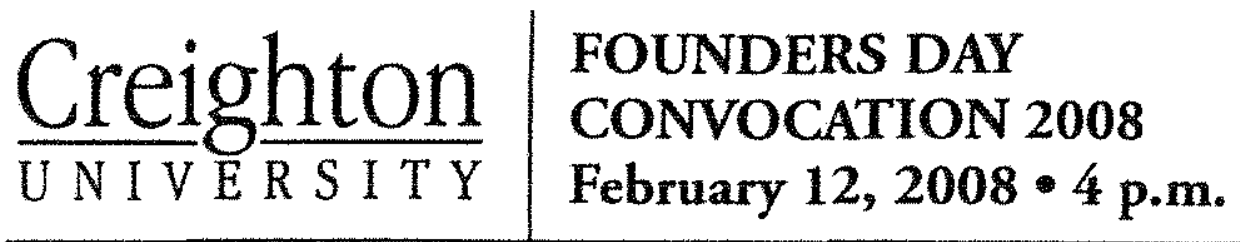

Award Citarions In Order of Presentation

\section{Arthur F. Fishkin, Ph.D. \\ Professor Emeritus of Biomedical Sciences}

Dr. Arthur F. Fishkin's service to Creighton University, its Health Science schools and the College of Arts and Sciences has been substantial and extensive, covering four decades.

Prior to joining Creighton in 1968, Dt. Fishkin held reaching posts at Louisiana State Universiry School of Medicine and at New Mexico State University. He earned his doctor of phitosophy degree in biochemistry as the University of lowa in 1957.

Ar Creighton, Dr. Fishkin has taught molecular and cell biology classes for the School of Medicine. For students in the Health Science Schools, he has taught undergraduate and graduate level biochemistry courses in the classroom, as well as online. His foundation course in human nutrition, entitled Nurrition Facts and Fads, has been an important resource fot students in the College of Arts and Sciences.

Since the formarion of the Department of Biomedical Sciences, Dr. Fishkin has served as a mentor for junior faculry and is held in highest regard by his deparment colleagues.

In addition, Dr. Fishkin has given valuable input to the School of Medicine's Admissions Commitsee, which is a challenging responsibility, In a given year, the hours spent reviewing applications, participating in meetings and conducring student interviews can easily add up to 200 hours.

Dr. Fishinin is an acrive member of the American Sociery of Biochemistry and Molecular Biology, and of the Annerican Chemical Society. He serves as a judge of abstracts for the Midwest Student Medical Forum.

For outstanding contributions and length of service, it is with pride and gratitude that Creighron University confers the rank Professor Emeritus of Biomedical Sciences upon Dr. Arthur F. Fishkin. 
SOUTH. BRAZ. J. CHEM., Vol.19, No. 19, 2011

L. G. Ionescu

We first met Prof. Dr. Arthur F. Fishkin in August of 1965 in Las Cruces. We had just completed the studies tor the M.S. Degree in Chemistry doing research on organic liquid scintillators under the supervision of Prof. Guido H. Daub of the University of New Mexico and Dr. Francis Newton Hayes of the Los Alamos Scientific Laboratory and were beginning the studies for the Ph.D. Degree with Prof. John J. Monagle, who was chairman of the Chemistry Department at New Mexico State University and was working with phosphorus organic compounds.

The Chemistry Department at NMSU was one big happy family at the time. Both the faculty and the graduate students were enthusiastic about the new Doctoral Program in Chemistry that had just begun. All of the young faculty members, including Prof. Dr. A. F. Fishkin, were working very hard to establish research groups, research laboratories and obtain research grants.

Two faculty members were responsible the biochemistry area:

A. F. Fishkin and O. B. Weeks and both joined NMSU in 1964.

Dr. Owen B. Weeks had a joint appointment as Research Professor of Chemistry and Biology, was really microbiologist and spent most of 
SOUTH. BRAZ. J. CHEM., Vol.19, No. 19, 2011

68

Arthur F. Fishkin, Prominent Biochemist and Educator

his time in the Research Center and the Department of Biology.

We remember Prof. Dr. Arthur F. Fishkin as a very friendly

person. He talked to almost all of the graduate students, used to go drink coffee with them in the Student Union, tell jokes or engage in serious discussions and conversations about many topics. He was an erudite person and some people were considering him a "walking encyclopedia".

He told us that he came to Las Cruces to help establish the program in biochemistry and to continue the research on glycoproteins in blood vessels in cows, since the genetics in the bovine species was much better documented than in humans.

Unfortumately and surprisingly, in the middle of 1966 , Prof. John J. Monagle announced that he was leaving to the University of Alabama, Tuscaloosa, to become Chairman of the Chemistry Department. It was part of a strong and general effort of Governor George C.Wallace to strengthen science and engineering and attract industry to the State of Alabama.

The impact of J.J. Monagle's decision was not a very good one for the Chemistry Department at NMSU and eventually it affected the lives of many people. 
SOUTH. BRAZ. J. CHEM., Vol.19, No. 19, 2011

L. G. Ionescu

In September of 1966 we enrolled in Medical School and after completing the first year we spent the summer of 1967 working with Prof. John J. Monagle as a Technical Assistant at the University Alabama.

In September of 1967 , we decided to return to Las Cruces and complete the studies for the Ph.D. in Physical Chemistry under the supervision of Prof. Dr. Gordon J. Ewing, investigating the interaction of leguminous hemoglobin with nitrogen and xenon. Leguminous hemoglobin, leghemoglobin or legoglobin is a protein and respiratory pigment found in the root modules of many plants that fix nitrogen. It was during this period (1967-68) that we interacted more with Prof. Arthur F. Fishkin and he helped us with the extraction and separation of leguminous hemoglobin from soybean root nodules.

The atmosphere in the Chemistry Department at NMSU had changed completely. There was animosity among the younger faculty members and one could feel the presence of envy, pettiness, jealousy and vanity, characteristic of the ivory towers of universities throughout the world. The new chairman (1967-71), Basil G. Anex, a specialist in reflectance spectroscopy, who had come from Yale, was not a very efficient administrator and later it took a lot of effort on the 
SOUTH. BRAZ. J. CHEM., Vol.19, No. 19, 2011

part of Prof. Latimer R. Evans and Ralph G. Wilkins to normalize the situation.

Prof. Dr. Arthur F. Fishkin had managed to set up the best equipped laboratory, had research grants from NASA and NIH and the largest research group (10-15 graduate students). We needed his help and assistance in the separation of leguminous hemoglobin from the root nodules. The process was a rather complicated, laborious and repetitive one and involved, among others, precipitation, fractionation, sedimentation with an ultracentrifuge, dialysis and gel electrophoresis. Prof. Fishkin's only condition for his help was that we go first to drink coffee in the Student Union.

It was during our trips to the Student Union that we got to know each other relatively well. Since I was not formally his student, he felt very much at ease. We used to talk about many topics other than science, including history of the United States, Mexico, Bessarabia, Romania and Russia, literature, art, wine, politics, the news of the day and other subjects.

During the 1960's the United States returned to Mexico a small strip of EI Paso that became part of the United States after the Rio Grande River changed its course (EI Chamizal). The Mexican 
SOUTH. BRAZ. J. CHEM., Vol.19, No. 19, 2011

L. G. Ionescu

Government celebrated the event and built shopping center, hotel, museums, monuments, water falls, parks, etc. in part of EI Chamizal (PRONAF-Programa Nacional Fronterizo), Prol. A. F. Fishkin used to say that this was Juarez's answer to Fifth Avenue and that it was a damned good one. Many students from New Mexico State University used to visit Mexico to see "Fishkin's Fifth Avenue" in Ciudad Juárez.

Some peoples have a high resistance and tolerance to alcohol, while ohers get drunk easily. Prof. A. F. Fishkin, who was a specialist in enzymology, had a theory on resistance or tolerance to alcohol. The metabolism of alcohol depends on enzymes. According to him, peoples that have consumed alcohol for many generations developed more and better enzymes.

He was an adept of the pheromone theory (today's Chemistry of Love) and used to give as an example a medical student who sensed the phermones that his girl friend sent from hundreds of miles away.

As we mentioned above, in 1967 Prof. Dr. Arthur Fishkin had the largest number of graduate students and had research grants from NASA and NIH. He had a lot of research money and all of them had research assistantships. About half of them were working on 
SOUTH. BRAZ. J. CHEM., Vol.19, No. 19, 2011

glycoproteins from cattle and the other half on the extraction of proteolytic enzymes from dermestid beetles. The fad of the time was to make trips in the Gila Wildermess, especially on horse back. Most of Prof. Fishkin's students were going on weekly mounted expeditions and were renting the horses. After some time, they decided that it was more convenient to buy horses. Each one of them had a horse and they used to keep them at stables in Mesilla Park. Some of them began neglecting research work in the laboratory and this used to upset Prof. A. T. Fishkin. He used to say jokingly that perhaps he should change research from cows to horses and that he was the only "Assistant Professor West of the Pecos River with a Mounted Cavally Unit?".

The photograph on the following page was taken during a visit to NASA's headquarters in Houston in 1964. It probably had to do with NASA's support of the Biochemistry Program at NMSU and the domation of laboratory equipment to the Chemistry Department after the closing of the Primate Facility near Alamogordo. It is well known that the first astronaut was LAIKA, the female shepherd dog that the Russians sent to space. The first American astronauts were 


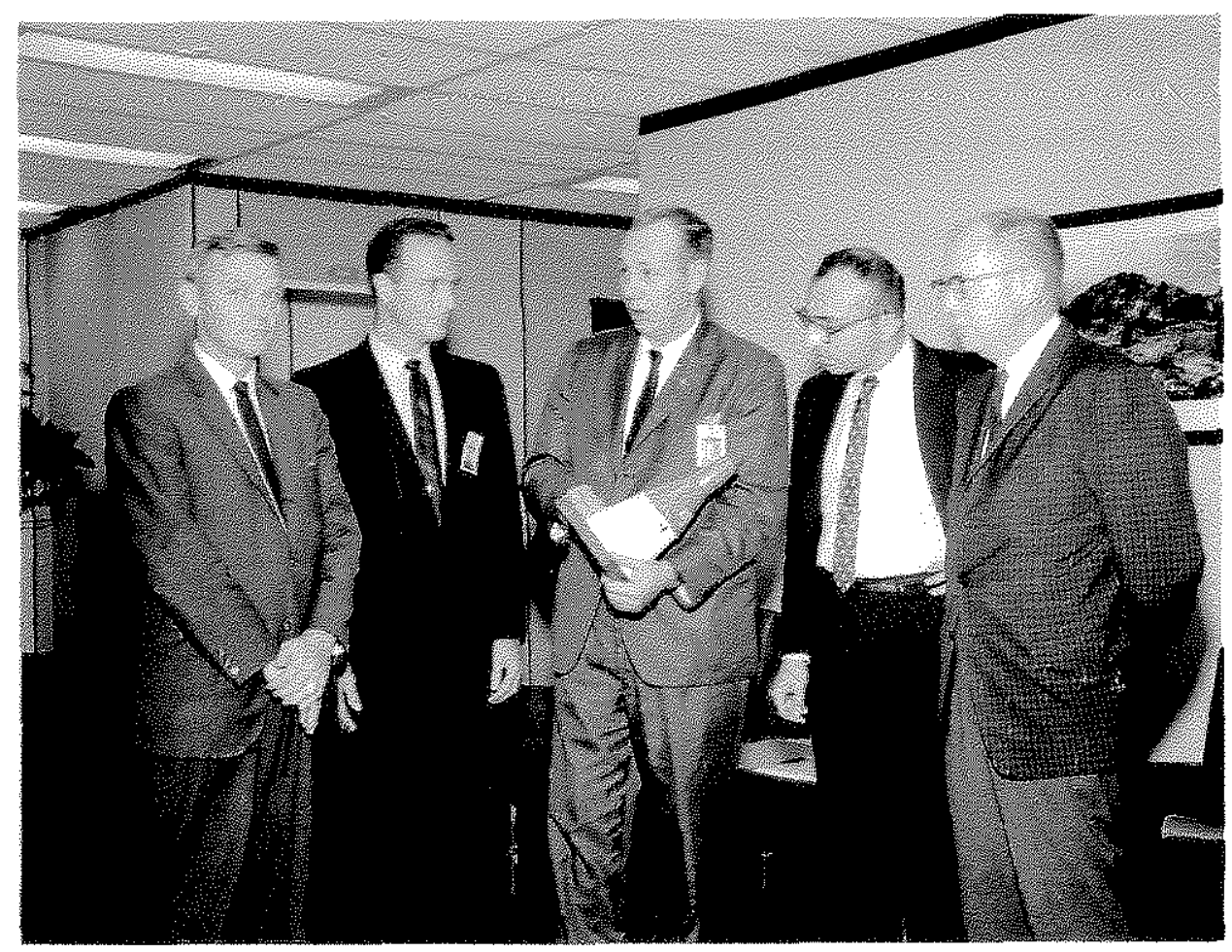

Picture laken in 1964 at NASA's Manned Space Center in Houston Texas, now called the Johnson Space Center.

From left to right: Owen B. Weeks, Scott Carpenter (Gemini Astronaut), Paul Purser (Senior NASA Official), Arthur F. Fishkin and James Weiss (Director of the Research Center, New Mexico State University).

two chimpanzees, HAM and ENOS, trained at the Primate Facility and sent to space in 1961.

Two graduate students, Peter N, Spangler and Philip J. Witt completed their Master of Science theses with Prof. Dr. A. F. Fishkin as advisor at New Mexico State University in 1968. These were probably the first graduate theses in biochemistry at NMSU. 
SOUTH. BRAZ. J. CHEM., Vol.19, No. 19, 2011

\section{Arhur F. Fishkin, Promoineme Biochemist and Educator}

74

Peter N. Spangler's work dealt with glycoproteins in fetal and adult cattle aortas and part of it was published in Nature in 1968.

Philip J. Witt worked in a new area and studied the selected proteolytic activity by of dermestid beetle larvae. This was a new area of research that Prof. A. F. Fishkin began in Las Cruces, remained in the initial stages and apparently he was not able to comtinue at Creighton University.

Dermestid beetles are part of the family of Coleoptera. They are scavengers that feed on plant and animal material and are sometimes employed to clean bones and skeletons and are known to contain proteolytic enzymes. The idea was to isolate, characterize and study the activity and property of these enzymes.

In the following pages we reproduce some figures, tables and diagrams that deal with these two topics and that we have received through the courtesy of Charles A. Fishkin, son of Prof. A. F. Fishkin and Senior Vice-President of Alliance Bernstein, New York, USA.

The material is self-explanatory and meeds no additional comments. 
SOUTHERN BRAZILIAN, JOURNAL OF CHEMISTRY

SOUTH. BRAZ. J. CHEM. , Vol. 19,No.19, 2011

\section{G. Ionescu}

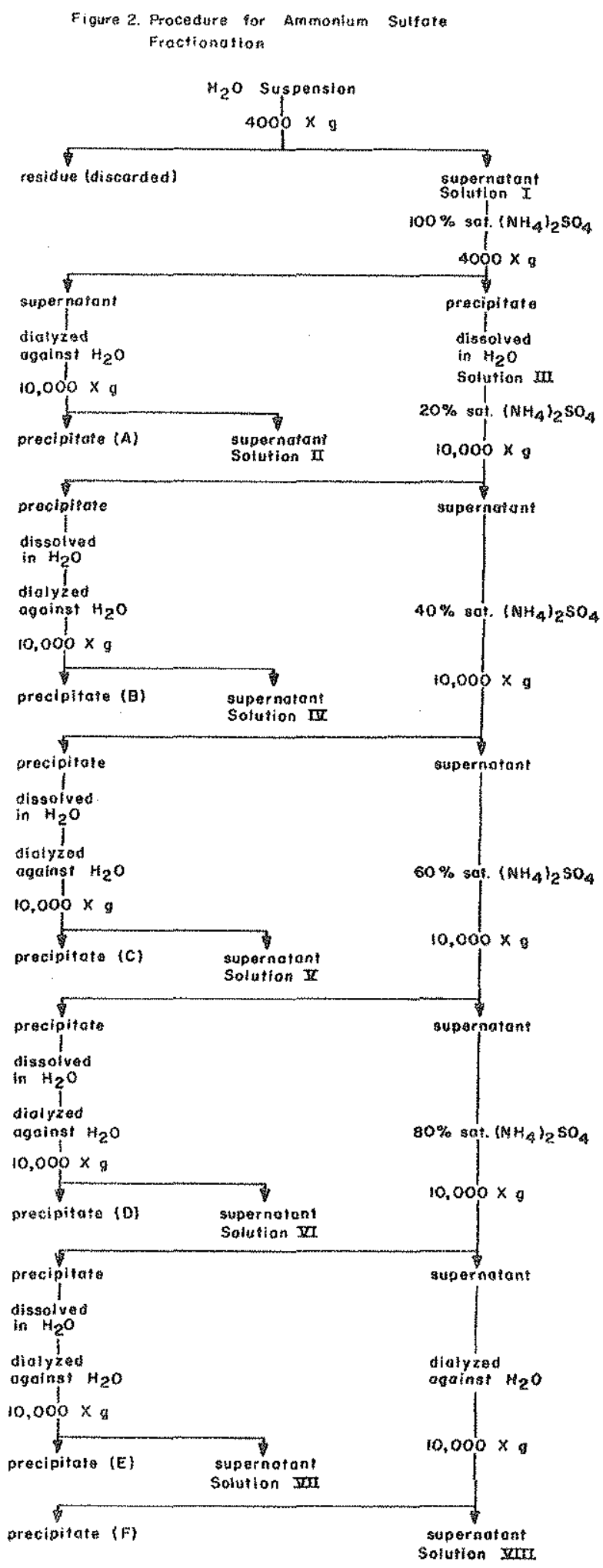




\section{SOUTHERN BRAZILIAN, JOURNAL OF CHEMISTRY}

SOUTH. BRAZ. J. CHEM., Vol. 19, No.19, 2011

Arthur H. Fishkin, Prominemt Biochemist and Educator

Peter N. Spangler, "Glycoproteins in Fetal and Adult Cattle Aortas", M.S. Thesis, New Mexico State University, April 8, 1968

Advisor: Prof. Arthur T. Fishkin

Figure 3.

ELECTROPHORETIC PATTERNS OF AORTA GLYCOPROTEIN

STAGE OF DEVELOPMENT

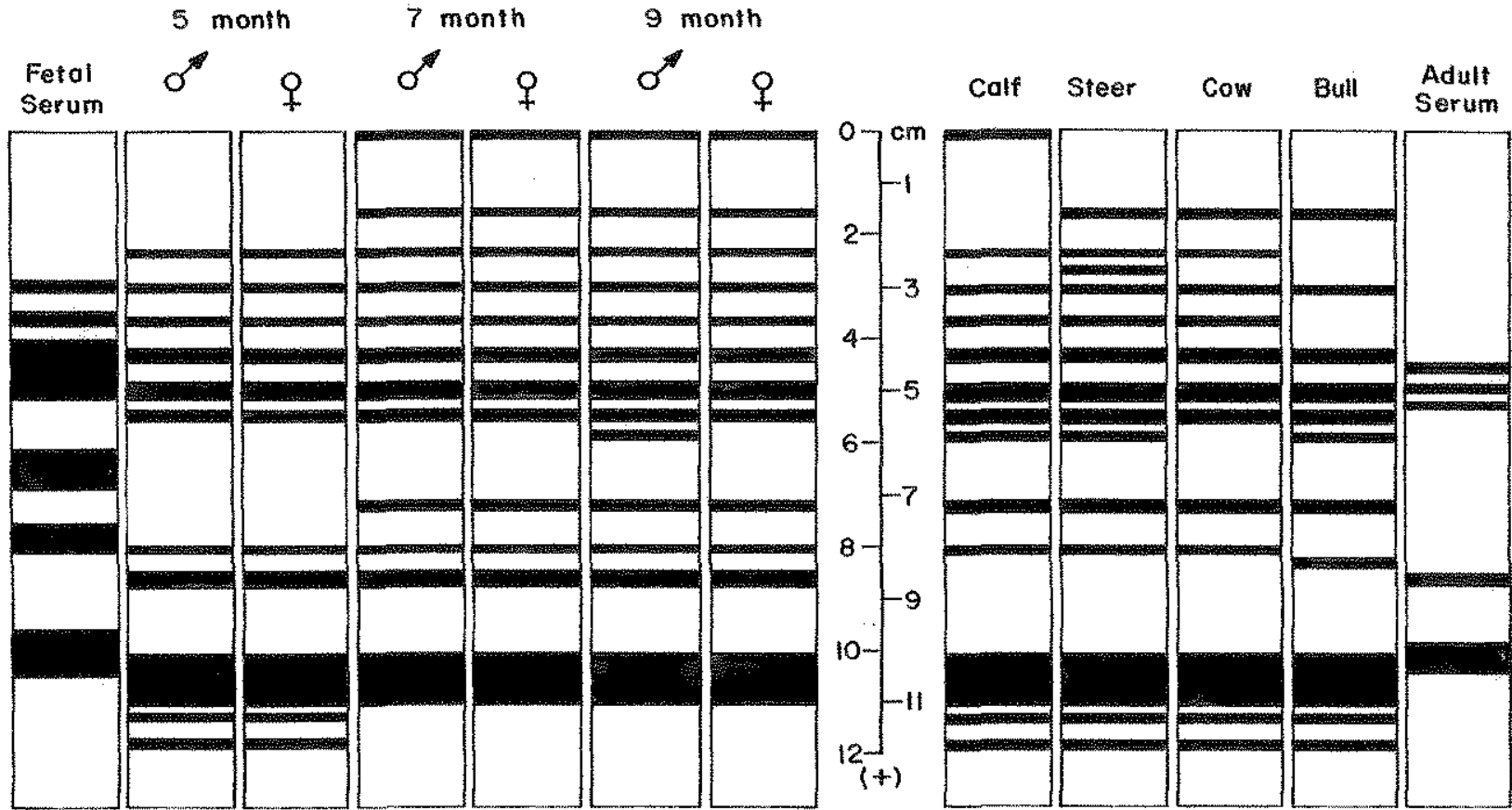

VISTT OUR SITE: http://www.sbjchem.he.com.br 
SOUTH. BRAZ. J. CHEM., Vol.19, No. 19, 2011

\section{L.G. Lonescu}

UMBILICAL BLOOD VESSEL GLYCOPROTEINS

ELECTROPHORETIC PATTERNS
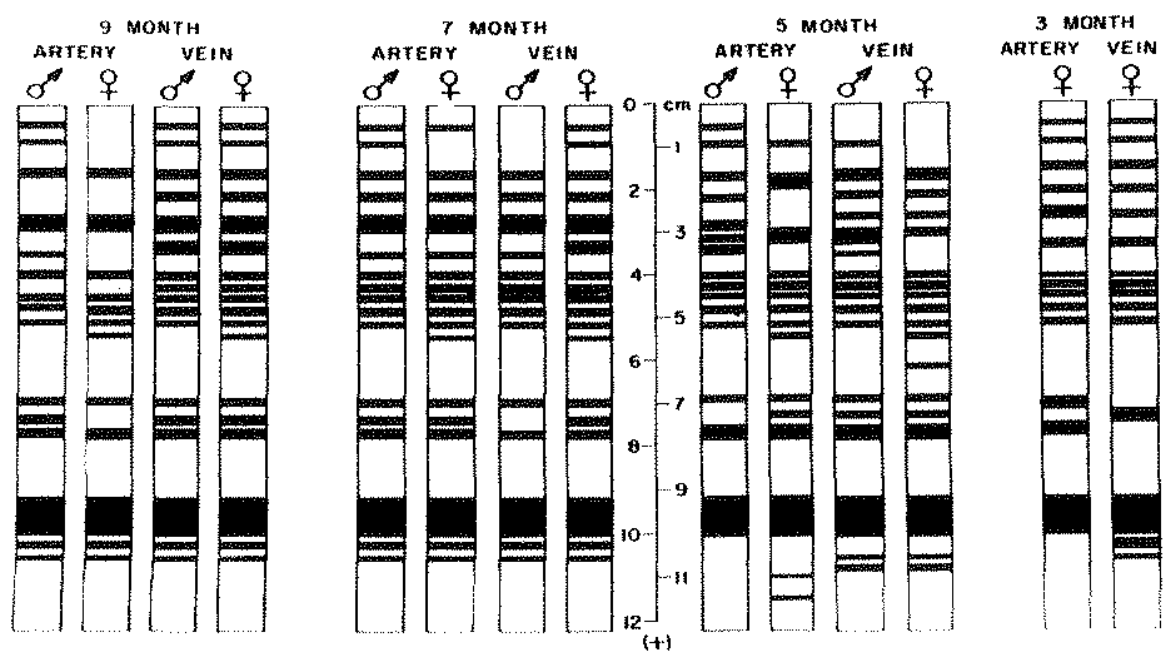

PERCENT COMPOSTTION OF GLYCOPROTETN FRACTTONS

Umbilical Artery Umbilica1 Vein

Neutral Sugars

Hexosamine

Sialic Acid

Nitrogen
3.0

1.4

3.4

14.4

15.2 


\title{
SOUTHERN BRAZILIAN, JOURNAL OF CHEMISTRY \\ SOUTH. BRAZ. J. CHEM. , Vol. 19,No.19, 2011
}

\author{
Arthur F. Fishkin, Prominent Biochemist and Educator
}

78

\section{NEW MEXICO STATE UNIVERSITY}

COLLEGE OF ARTS AND SCIENCES

CHEMISTRY DEPARTMENT
LAS CRUCES. NEW MEXICO 8800: PHONE 646.2505 OR 646.2506

Abstract for ACS Meeting-in-Minature on Apri1 15, 1967

\author{
Gelatinolytic Activity of Extracts Prom the Larae of Dermestid \\ Beeliles \\ P. J. Witt and A. F. Fishkin \\ Department of Chemistry \\ New Mexico State University
}

Recently enzymes which hydrolyze collagen and its degradation product gelatin have been' demonstrated in developing animal systems Collagen is a ubiquitous and important stmuctural component of a.1 connective tissue. The catabolyc steps by which this macromolecular species is handled is nobtwell understood. The larvae of dermestid beetles are knowa to subsist on collagenous substrates. It would appear that these larvae could provide a source of enzymes which cataly the degradation of collagen and gelatin. Water extracts of the larvae of Dermestes maculatus hydrolyze $20.5 \%$ solution of gelatin. Fractional precipitation with amonium sulfate yields three Practions capable of bydrolyzing gelatin. One fraction is precipitated by 20 saturated ammonigm sulfate; the other two, which seem. quite similar to each other, precipitate in excess of $40 \%$ saturation. The fraction precipitating at $60 \%$ saturation exhibited a 30 fold increase in specific activity as compared with the initial crude extract. The enzyme fractions lost approximately $50 \%$ of their activity after considerable freezing and thawing over a period of two months. Assay of the gelatinolytic activity was made by a viscometric method. This work was supported in part by NASA grant IVGR 32-0 3- 27 to New Mexico State University.

VISIT OUR SITE: http://www.sbjchem.he.com.br

OPEN ACCESS. This article is licensed under a Creative Commons Attribution 4.0 (CC BY 4.0) International License, which permits use, sharing , adaptation , distribution , and reproduction in any medium or format, as long as you give appropriate credit to the original author (s) and the source, provide a link to the Creative Commons license, and indicate if changes were made. The images or other third-party material in this article are included in the article's Creative Commons license unless indicated otherwise in a credit line to the if changes were made. The images or other third-party material in this article are included in the article's Creative Commons license unless indicated otherwise in a credit line to the
material. If material is not included in the article's Creative Commons license and your intended use is not permitted by statutory regulation or exceeds the permitted use, you will need to obtain permission directly from the copyright holder. To view a copy of this license, visit http://creativecommons.org/ licenses/by/4.0/. 